\title{
Efficacy of Milk Fluoride Prevention of Dental Caries in Children Under 12 Years Old: A Review
}

\author{
Eficacia de la Leche Fluorada en la Prevención de Caries \\ Dentales en Niños Menores de 12 Años: Una Revisión
}

Mariela Torres E..; Patricio Oliva M. * \& Camila Lecannelier B..

TORRES, E. M.; OLIVA, M. P. \& LECANNELIER, B. C. Efficacy of milk fluoride prevention of dental caries in children under 12 years old: A review. Int. J. Odontostomat., 10(2):197-206, 2016.

ABSTRACT: Dental caries is the most common infectious-contagious worldwide disease that can be prevented with fluoride. Since milk is an important part of children's diets, it is a good choice as vehicle to deliver fluoride. The objective of the study was to determine the efficacy of fluoridated milk as a systemic prevention to prevent dental caries in children under 12 years old. This is a systematic review with narrative analysis. It develops search strategies in all kinds of studies databases without language restrictions. An overview table was done describing: author, method, statistical type, comparison group, outcome type, sample / universe, patient type, intervention type and adverse effect. The results showed that fluoride milk is effective in preventing dental caries. Since milk already contains elements which prevent dental caries, adding the appropriate amount of fluoride would increase the protective effect against them.

KEY WORDS: fluoridated milk, dental caries, milk without fluoride.

\section{INTRODUCTION}

Dental caries is a multi-factorial, highly transmissible disease of dental tissues (Itthagarum et al., 2011) that results from the production of acids in bacterial biofilms (dental plaques) on the tooth surface which causes localized destruction of the teeth (Pratten et al., 2000). The etiology includes elevated colonization levels of mutants streptococci, high frequency sugar consumption, and developmental defects on primary teeth (Tinanoff et al., 2002).

The progression or reversal of the caries process depends on the balance between pathological and protective factors (Itthagarum et al.). In some communities dental caries is on the increase, and this may be in part due to increasing use of refined sugars and inadequate exposure to fluoride (Itthagarum et al.). World Health Organization reports $60-90 \%$ of schoolchildren worldwide have experienced caries, with the disease being most prevalent in Asian and Latin American countries (Prasai et al., 2013).

The prevalence of early childhood caries increased withage, and the number of sugary snacks between meals and a cariogenic diet were strongly related to early childhood caries (Rosenblatt \& Zarzar, 2004). Modern Dentistry has been developing new concepts on early care and on health maintenance, contributing to the decrease in the prevalence of dental caries (da Silva et al., 2013).

Caries can be prevented by perfect oral hygiene and sugar abstinence (Zimmer et al., 2003). However, practice has shown that this approach is successful in individual cases only. For the whole population, effective caries prevention is still not realistic without the use of fluoride in various forms (Zimmer et al.).

Fluoride has been identified as one of the protective factors, which tilts the caries balance towards the positive side (Itthagarum et al.), and the use of fluoride by various means has been shown to be effective in preventing dental caries (Bian et al., 2003) because the constant presence of low levels of fluoride in the mouth inhibits de-mineralization and enhances re-mineralization (Itthagarum et al.) also inhibiting bacterial growth (Jacobsen \& Young, 2003). 
Remineralization involves the deposition of calcium phosphates from saliva to rebuild partly dissolved enamel crystallites (ten Cate, 2013). When fluoride is incorporated the dissolution of these reinforced crystallites will be reduced during a subsequent sugar-induced and bacteria-mediated acid attack (ten Cate).

The major cause of this reduction has been shown to be the introduction of systemic and topical fluorides, systemic being through use of water, milk or salt as vehicles, and topical mainly through the use of fluoridated toothpaste (Mulyani \& Mclntyret, 2002).

Oral health programs tend to concentrate on individual behavior change and largely ignore the influence of socio-political factors as the key determinants of health (Sheihamand \& Watt, 2000). There is a close relationship between health level and cultural and socioeconomic disadvantage (da Silva et al.).Food policy development and the Health Promoting Schools initiative are used as examples of effective ways of promoting oral health (Sheiham \& Watt). Oral health promotion which brings about the use of fluoride is effective for reducing caries (Kay \& Locker, 1998).

Fluoride continues to be the cornerstone of any caries prevention program and is administered, in many regions of the world, by fluoridation of the water supply (Pratten et al.). Although water and toothpastes have been excellent vehicles for fluoride, there are parts of the world where drinking water cannot be fluoridated due to reasons such as the lack of resources, socioeconomic and technical con-strains, absence of political will and national policy on oral health (Itthagarum et al.).

It was found that, for the Chilean situation, milk fluoridation is, at least, 1,000 times more economic than water fluoridation (Villa et al., 1990).

The Swiss pediatrician Ziegler (1953) recommended that milk could be used as an alternative vehicle to deliver fluoride (Malinowski et al., 2012). Milk is a good vehicle for providing fluoride to children, and fluoridated milk is technically easy to make (Bian et al.) and forms an important part of children's diets, having natural caries-protective and health-promoting components (Yeung et al., 2005). Milk was one of the most important foodstuffs in the total energy consumption (Hinnig \& Bergamaschi, 2012). The findings confirm that milk seem to be a suitable vehicle for fluoride administration (Engström et al., 2006).
The slow fermentable lactose in milk is less cariogenic than sucrose, and the proteins and fats in milk may have a cariostatic effect too (Bian et al.). Fluoride added to milk does not change its taste and other characteristics (Bian et al.); and is well tolerated and safe from a toxic point of view (Engström et al.).

Milk as a common nutrient seems to play a complex role in in-vitro biofilm--enamel interactions stimulating bacterial demineralization on one hand, and, as effective fluoride carrier, inhibits caries-like demineralization (Arnold et al., 2006). It was possible to verify an inhibition of enamel lesion formation by fluoridated milk already after $40 \mathrm{~h}$ of acid exposure and before any clearly visible clinical signs of demineralization were seen (Engström et al.).

Fluoridation of milk is recommended where fluoride concentration in the drinking water is suboptimal, caries experience is significant and programs to provide milk to children are in place (Itthagarum et al.) it was confirm that the earlier in the child's life the consumption of fluoridated milk starts, the better the effect (Ivanova et al., 1995).

Dental caries and forms of prevention have been the subjects of many studies. Fluorinations of foods that are high-consumption as milk have been analyzed as prevention. The following paper consists of a systematic review about efficacy of milk fluoride prevention of dental caries in the children under 12 years old.

\section{MATERIAL AND METHOD}

This is a systematic review with narrative analysis. It develops search strategies in all kinds of studies databases without language restrictions.

Types of participants. Children under 12 years old who had access to fluoridated milk and those who did not.

Types of interventions. Interventions that involved fluoridated milk compared to non-fluoridated administered to children under 12 years old to measure the tooth decay prevention incidence. The systemic fluoride (milk) works as a caries development controller (prevention), the effect of adding fluoride to milk distributed on supplement or public health programs and the effect of fluoridated milk in a bacterial biofilm 
formation were also measured. Studies that did not meet this criterion are excluded.

The interventions that studied a different systemic fluoride to milk, risk for fluorosis, studies of components of milk, and the effect of breast milk to the teeth and dental caries and the analysis of the fluoride that the food contains were excluded.

Types of measures outcomes: a) Primary measures outcomes, b) Data on caries experience, c) Caries incidence, d) Concentration of ppm fluoride ion ( $\mathrm{mg} / \mathrm{L}$ ) in solution as $\mathrm{NaF}$ and e) Caries increment. Secondary measures outcomes: a) Measures of general health.

Search strategy for the identification of studies. We searched the Cochrane Central Register of controlled trials (CENTRAL), Clinicaltrial.gov. An additional search was realized using a search strategy in MEDLINE route Pubmed (from 1998 until 2013), Lilacs (from 1998 until 2013), Ebsco (from 1998 until 2013), EMBASE (via OVID; 1998-2013), Science Citation Index (19982013), and Google scholar.

Selection of the studies. All references identified by the search strategy will be reviewed by two authors who independently will review and judge if the studies meet the inclusion criteria.

Disagreements will be resolved by discussion. If there is no agreement a third author will be prompted to settle those differences. Publications were excluded: a) without editorial board, b) diffusion magazines (organizational, laboratories, companies, etc.) c) conference abstracts. Scientific publications and analyzable methodology is privileged, and consistent with the objective of the research.

Question of search: What is the effectiveness of fluoridated milk compared with non-fluoridated milk in children under 12 years old to dental caries prevention?
The variables are analyzed according to the type of patient, methodological intervention comparison group, and outcome (Table I)

Review Methods. The review methods will be evaluated by two authors independently, focusing on search results and selection criteria. Researchers' criteria differences will be resolved by consensus among them. The Objective is: To determine the efficacy of fluoridated milk as a systemic prevention to prevent dental caries. The Type of studies is all kinds of studies that investigated the efficacy of fluoridated milk for dental caries prevention will be used. The excluded studies are those that: they had no clear methodology, showed conflicting results and presented ambiguous data, clear designs confusing or inadequate statistical data.

\section{RESULTS}

The method of each study is analyzed in order to know the type of design used, then the type of statistician to establish the mathematical depth with which the research was conducted, whether there is a comparison group or not, the type of outcome related to the sample/universe, the type of patients and intervention made in each study, and also an additional result the adverse effects were evaluated (Table I)

The results of evidence are summarized in the following points:

a) The milk fluoridation as an anti-caries measure, as they demonstrate that the addition of fluoride to milk increases the $\mathrm{pH}$ of the biofilms (Bian et al.).

b) The milk fluoridation is a caries inhibitory effect (Kay \& Locker).

Table I. Study variables.

\begin{tabular}{lccc}
\hline Patients & Intervention & Comparison & Outcome \\
\hline $\begin{array}{l}\text { Pediatric patients under 12 } \\
\text { years old. }\end{array}$ & $\begin{array}{c}\text { The fluoride milk efficacy in } \\
\text { the incidence of dental caries. }\end{array}$ & $\begin{array}{c}\text { Incidence of dental caries between } \\
\text { children who drink fluoridated milk from } \\
\text { those who drink non fluoridated milk. }\end{array}$ & $\begin{array}{c}\text { Incidence of dental caries } \\
\text { (apparition of dental cavity). }\end{array}$ \\
\hline $\begin{array}{l}\text { Associated to the } \\
\text { Search }\end{array}$ & $\begin{array}{c}\text { Associated to the } \\
\text { Search }\end{array}$ & Secondary outcome \\
\hline--- & Milk fluoridation & Milk fluoride \\
--- & Milk fluoro & --- & Dental caries \\
--- & & Childhood caries & ---
\end{tabular}


c) No adverse effects reported in selected studies. The correct dose is important to prevent diseases like or fluorosis.

d) The effectiveness of fluoride in milk depends on: the promotion of oral health in caries, oral hygiene, oral health knowledge, attitudes and behaviors.

e) The mothers influence positively in the maintenance treatment of fluoridated milk (da Silva et al.)

The studies used observational designs. Studies focus on population-based epidemiological assessments that consider particular groups of subjects (mother - child), analyzing clinical treatments, education and adherence to treatment. Statistically, Research inferential statistics used to compare the results of fluoridated milk between groups or over time in one or more groups. This is used for testing in research such as ANOVA or T Student.

The structure of the research results show some development on the issue of fluoridated milk, lacking appropriate clinical trials for evaluation of efficacy. Evidence focuses on specific investigations of different quality and without adequate continuity to conduct a metaanalysis or some type of statistical analysis synthetic. The topic of fluoridated milk has contextualized information or methodology, in which the synthesis and critical analysis is fundamental to development is an overview of this topic.

\section{DISCUSSION}

Knowledge acquisition is essential to improve oral health conditions (Prasai Dixit et al.). Caries, one of the most prevalent diseases of humans, results from the production of acids in bacterial biofilms (dental plaques) on the tooth surface which causes localized destruction of the teeth. The caries lesion results from the demineralization of tooth enamel by acid (Pratten et al.).

Caries preventive strategies in preschool children include diet modifications to reduce high frequency sugar consumption, supervised tooth brushing with fluoridated dentifrice, systemic fluoride supplements (Tinanoff et al., 2002) like the application of fluoride varnish that is an excellent topical form for those patients who have access to dental care (Jacobsen \& Young). However, considerable amount of school children had never been to a dentist nor had access to preventive hygiene practices (Prasai Dixit et al.).
Milk is an attractive vehicle for fluoride because it forms an important part of children's diets, having natural caries-protective (Yeung et al.), the consumption of milk will no doubt benefit the growth and development of young children. Therefore, by adding an appropriate amount of fluoride into the milk, simultaneous effects on dental caries prevention would be achieved (Bian et al.).

Trials in several countries have shown that children who participated in the fluoridated milk program experienced significantly less dental caries compared to children not on the program (Itthagarum et al.).

Fluoridated milk appears to have a protective effect on early enamel carious lesions (Itthagarum et al.). Studies have shown that fluoridated milk reduces the caries progression (Arnold et al.) and a clear doseresponse benefit of fluoride in milk has been demonstrated for the prevention of demineralization of enamel under a cariogenic challenge in vitro (Malinowski et al.).

It was possible to verify an inhibition of enamel lesion formation by fluoridated milk already after $40 \mathrm{~h}$ of acid exposure and before any clearly visible clinical signs of demineralization were seen (Engström et al.) and it was demonstrated that the addition of fluoride to milk increases the $\mathrm{pH}$ of the biofilms (Pratten et al.).

Studies also confirm that the earlier in the child's life the consumption of fluoridated milk starts, the better the effect (Ivanova et al.) and showed that increasing the volume of fluoridated milk has little effect on its remineralizing efficacy (Itthagarum et al.).

As an adverse effect, Enamel fluorosis can occur following either an acute or chronic exposure to fluoride during tooth formation (Mulyani \& Mclntyret).

Recommendation: Caries is a disease that can be prevented with hygiene, regular visits to the dentist, avoiding a cariogenic diet, all this can be supplemented through systemic methods, especially in view of the fact that not all people have access to the dentist or an education of proper hygiene.

A systemic prevention method is fluoridated milk, which is an important part of the diet of children making it suitable, as it also has its own beneficial properties. Because it was found to be effective in the prevention of tooth decay, it would be worthwhile considering especially when there is a milk delivery system to families, as there is in Chile. 
TORRES, E. M.; OLIVA, M. P. \& LECANNELIER, B. C. Efficacy of milk fluoride prevention of dental caries in children under 12 years old: A review. Int. J. Odontostomat., 10(2):197-206, 2016.

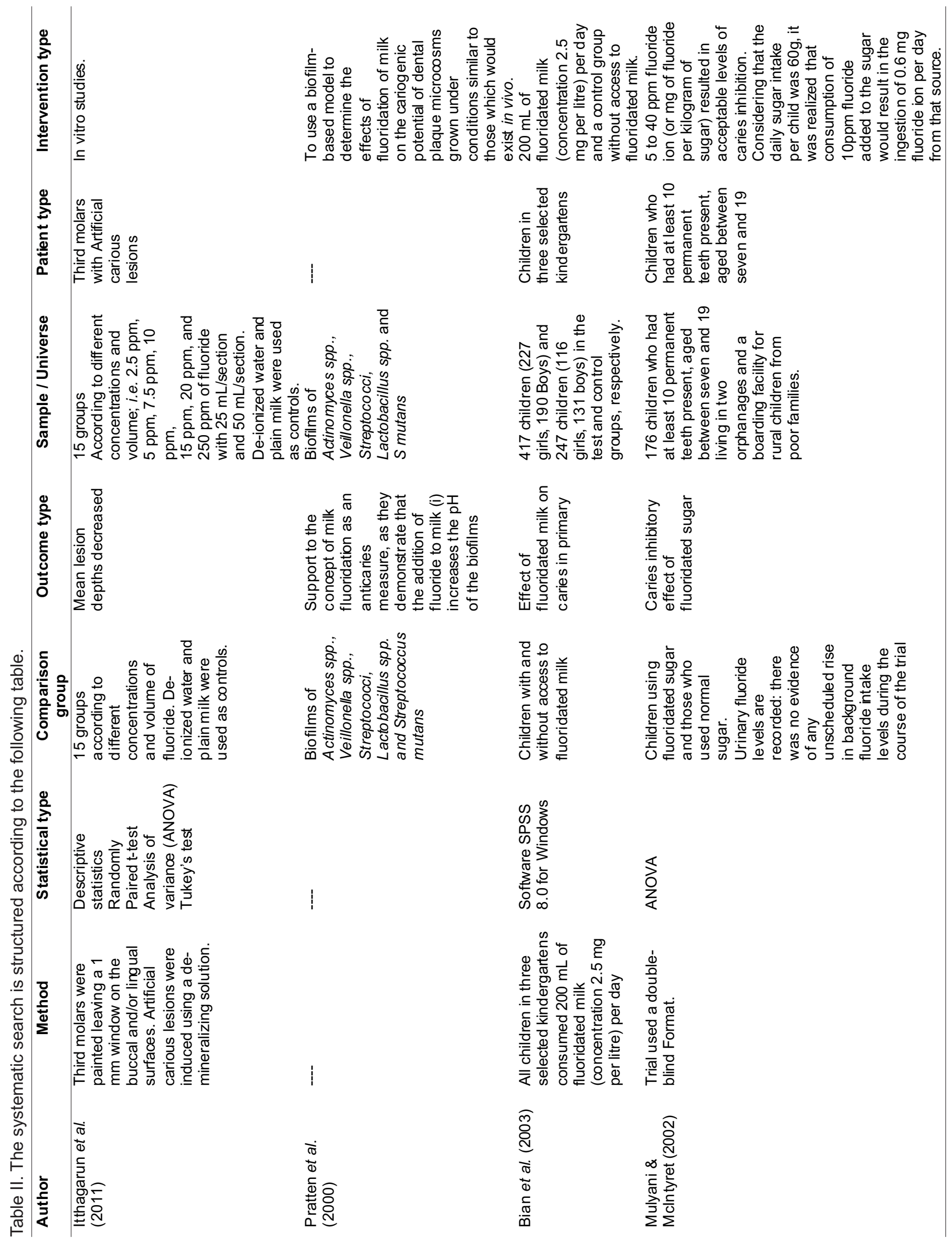


TORRES, E. M.; OLIVA, M. P. \& LECANNELIER, B. C. Efficacy of milk fluoride prevention of dental caries in children under 12 years old: A review. Int. J. Odontostomat., 10(2):197-206, 2016.

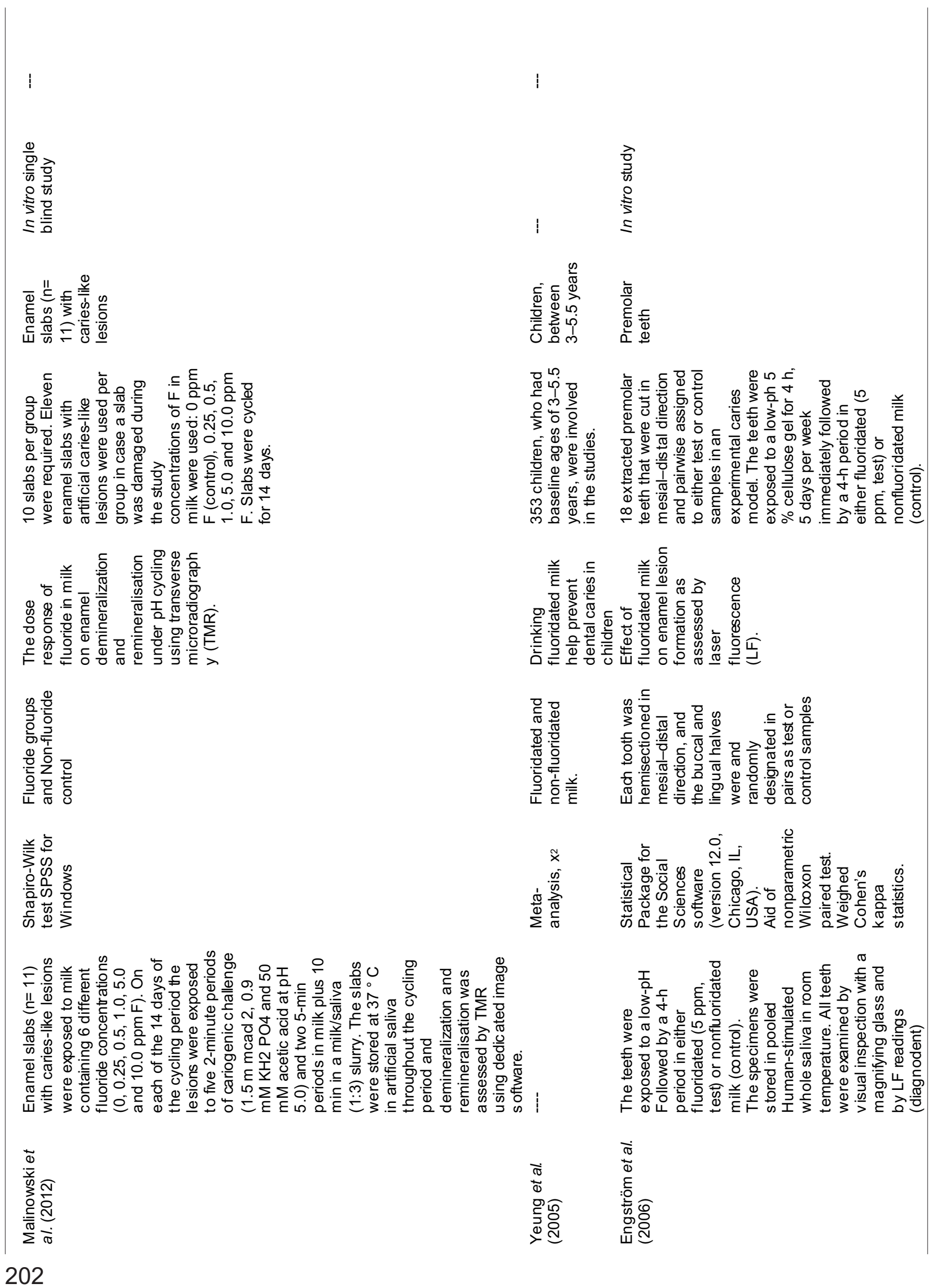




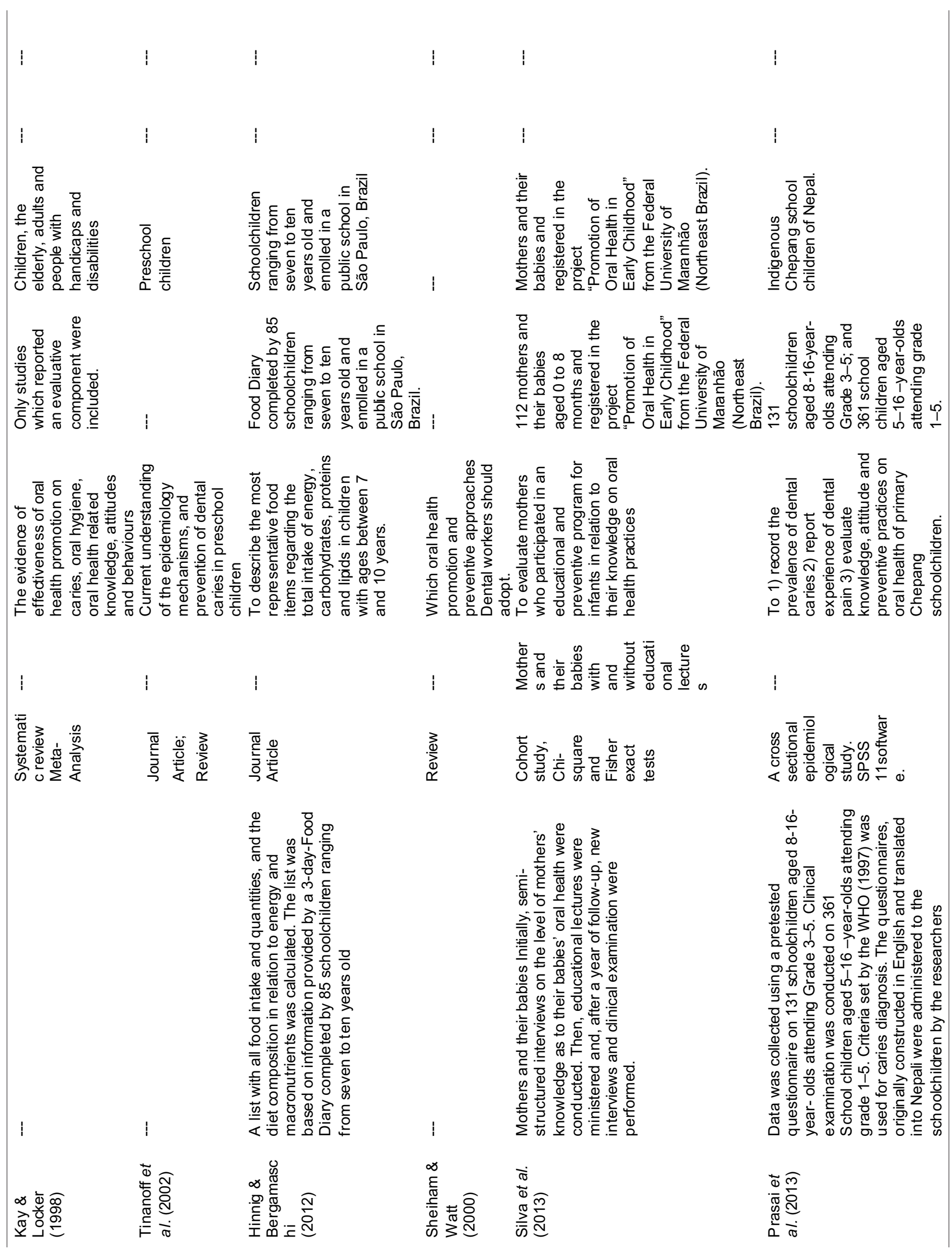


TORRES, E. M.; OLIVA, M. P. \& LECANNELIER, B. C. Efficacy of milk fluoride prevention of dental caries in children under 12 years old: A review. Int. J. Odontostomat., 10(2):197-206, 2016.

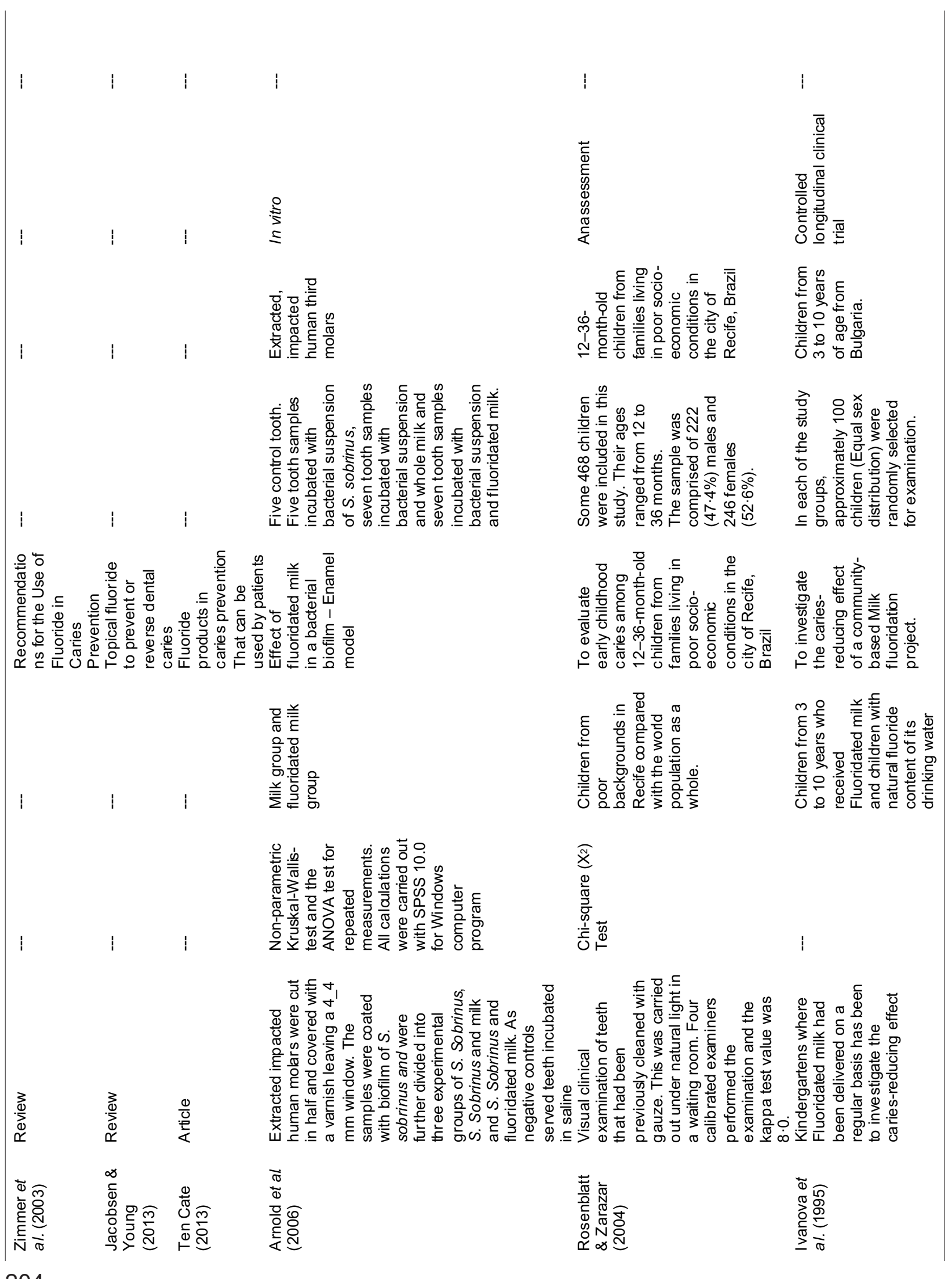




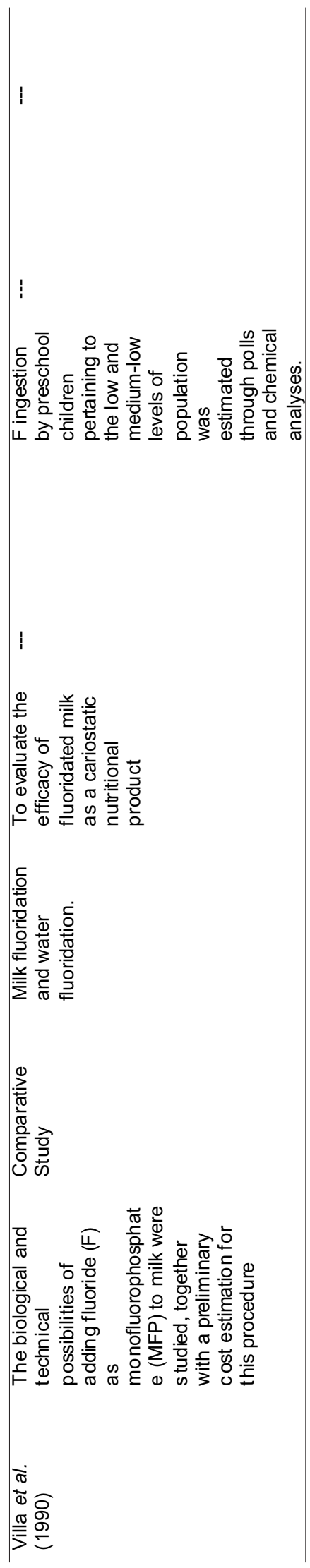

TORRES, E. M.; OLIVA, M. P. \& LECANNELIER, B. C. Eficacia de la leche fluorada en la prevención de caries dentales en niños menores de 12 años: Una revisión. Int. J. Odontostomat., 10(2):197-206, 2016.

RESUMEN: La caries dental es la enfermedad común que se puede prevenir con una correcta higiene y el uso de fluoruro. La leche es una parte importante de la dieta de los niños, por ende, una buena opción como vehículo para entregar fluoruro. El objetivo fue determinar la eficacia de la leche fluorada para la prevención de la caries dental en niños menores de 12 años. Se realizó una revisión sistemática con análisis narrativo. Se desarrolló estrategias de búsqueda en bases de datos sin restricciones de idioma ni de diseño. Se generó una tabla general describiendo: autor, método, tipo estadístico, grupo de comparación, el tipo de resultado, muestra / universo, tipo de paciente, el tipo de intervención y los efectos adversos. Se demostró que la leche fluoruro es eficaz para prevenir la caries dental. La leche poseen elementos que impiden la caries dental, la adición de la cantidad apropiada de flúor aumentaría el efecto protector contra ello.

PALABRAS CLAVE: leche fluorada, caries dentales, leche no fluorada.

\section{REFERENCES}

Arnold, W. H.; Forer, S.; Heesen, J.; Yudovich, K.; Steinberg, D. \& Gaengler, P. The in vitro effect of fluoridated milk in a bacterial biofilm--enamel model. Biomed. Pap. Med. Fac. Univ. Palacky Olomouc Czech Repub., 150(1):63-9, 2006.

Bian, J. Y.; Wang, W. H.; Wang, W. J.; Rong, W. S. \& Lo, E. C. Effect of fluoridated milk on caries in primary teeth: 21-month results. Community Dent. Oral Epidemiol., 31(4):2415, 2003.

da Silva, R. A.; Nóia, N. B.; Gonçalves, L. M.; Pinho, J. R. \& da Cruz, M. C. Assessment of mothers' participation in a program of prevention and control of caries and periodontal diseases for infants. Rev. Paul. Pediatr., 31(1):83-9, 2013.

Engström, K.; Petersson, L. G. \& Twetman, S. Inhibition of enamel lesion formation by fluoridated milk assessed by laser fluorescence--an in vitro study. Clin. Oral Investig., 10(3):249-52, 2006.

Hinnig, P. F. \& Bergamaschi, D. P. Food items in the food intake of children aged seven to ten years. Rev. Bras. Epidemiol., 15(2):324-34, 2012.

Itthagarun, A.; Verma, S.; Lalloo, R.; King, N. M.; Wefel, J. S. \& Nair, R. G. Effects of fluoridated milk on artificial enamel carious lesions: a pH cycling study. J. Dent., 39(12):817-24, 2011.

Ivanova, K.; Pakhomov, G. N.; Moeller, I. J. \& Vrabcheva, M. Caries reduction by milk fluoridation in Bulgaria. Adv. Dent. Res., 9(2):120-1, 1995.

Jacobsen, P. \& Young, D. The use of topical fluoride to prevent or reverse dental caries. Spec. Care Dentist, 23(5):177-9, 2003.

Kay, E. \& Locker, D. A systematic review of the effectiveness of health promotion aimed at improving oral health. Community Dent. Health, 15(3):132-44, 1998.

Malinowski, M.; Duggal, M. S.; Strafford, S. M. \& Toumba, K. J. The effect of varying concentrations of fluoridated milk on enamel remineralisation in vitro. Caries Res., 46(6):555-60, 2012. 
Mulyani, D. \& Mclntyret, J. Caries inhibitory effect of fluoridated sugar in a trial in Indonesia. Aust. Dent. J., 47(4):314-20, 2002.

Pratten, J.; Bedi, R. \& Wilson, M. An in vitro study of the effect of fluoridated milk on oral bacterial biofilms. Appl. Environ. Microbiol., 66(4):1720-3, 2000.

Prasai Dixit, L.; Shakya, A.; Shrestha, M. \& Shrestha, A. Dental caries prevalence, oral health knowledge and practice among indigenous Chepang school children of Nepal. BMC Oral Health, 13:20, 2013.

Rosenblatt, A. \& Zarzar, P. Breast-feeding and early childhood caries: an assessment among Brazilian infants. Int. J. Paediatr. Dent., 14(6):439-45, 2004.

Sheiham, A. \& Watt, R. G. The common risk factor approach: a rational basis for promoting oral health. Community Dent. Oral Epidemiol., 28(6):399-406, 2000.

ten Cate, J. M. Contemporary perspective on the use of fluoride products in caries prevention. Br. Dent. J., 214(4):161-7, 2013.

Tinanoff, N.; Kanellis, M. J. \& Vargas, C. M. Current understanding of the epidemiology mechanisms, and prevention of dental caries in preschool children. Pediatr. Dent., 24(6):543-51, 2002.

Villa, A.; Guerrero, S.; Cisternas, P. \& Mönckeberg, F. Caries prevention through a nutritional vehicle. Arch. Latinoam. Nutr., 40(2):197-208, 1990.

Yeung, C. A.; Hitchings, J. L.; Macfarlane, T. V.; Threlfall, A. G.; Tickle, M. \& Glenny, A. M. Fluoridated milk for preventing dental caries. Cochrane Database Syst. Rev., (3):CD003876, 2005.

Ziegler, E. Milk fluorination in prophylaxis of dental caries. Schweiz. Med. Wochenschr., 83(31):723-4, 1953.

Zimmer, S.; Jahn, K. R. \& Barthel, C. R. Recommendations for the use of fluoride in caries prevention. Oral Health Prev. Dent., 1(1):45-51, 2003.
Dirección para Correspondencia:

Facultad de Ciencias de la Salud

Universidad del Desarrollo

Barros Arana 1734

Concepción

CHILE

Fono: 041-2268544

Fax: 56-41-2268501

Email: mariela.torres.e@gmail.com

Received: 18-01-2015

Accepted: 03-06-2016 